\title{
Effects of the $\beta$-agonist, cimaterol, on growth, body composition and energy expenditure in rats
}

\author{
BY R. D. SAINZ AND J. E. WOLFF \\ Growth Physiology Group, Ruakura Agricultural Research Centre, Ministry of Agriculture \\ \& Fisheries, Hamilton, New Zealand
}

(Received 10 July 1987 - Accepted 12 February 1988)

\begin{abstract}
1. Male Sprague-Dawley rats weighing 146.5 (SE 4.3) g were fed on a semi-synthetic diet containing 0,25 or $150 \mathrm{mg}$ cimaterol $/ \mathrm{kg}$ for $12 \mathrm{~d}$. Net changes in weight and composition of carcass, liver, heart, gastrointestinal tract, gastrocnemius plus plantaris muscles, skin and remainder were estimated by comparative slaughter.

2. Cimaterol increased protein gains in gastrocnemius plus plantaris muscles from $0.09 \mathrm{~g}$ in controls to $0 \cdot 14$ and $0.12 \mathrm{~g}$ in 25 and $150 \mathrm{mg}$ cimaterol $/ \mathrm{kg}$ groups respectively. Carcass protein gains increased from $6.27 \mathrm{~g}$ in controls to 8.00 and $7.05 \mathrm{~g}$ in 25 and $150 \mathrm{mg}$ cimaterol $/ \mathrm{kg}$ groups respectively.

3. Rats treated with cimaterol either gained less fat or actually lost fat from all tissues studied, whilst control rats gained fat. These changes were reflected in lower energy retention in cimaterol-fed rats.

4. Energy intake was not affected by treatment. Cimaterol increased heat production from $776 \mathrm{~kJ} / \mathrm{kg}$ bodyweight $\mathrm{t}^{0.75}$ in controls to $863 \mathrm{~kJ} / \mathrm{kg}$ body-weight $\mathrm{t}^{0.75}$ in both treated groups. Gross efficiency was reduced from $17.4 \%$ in controls to 8.0 and $7.7 \%$ in rats fed on 25 and $150 \mathrm{mg}$ cimaterol $/ \mathrm{kg}$ diets respectively.

5. These results indicate that cimaterol increases protein gain at the expense of fat in rats. In addition, subcutaneous adipose tissue appears to be more sensitive than abdominal fat, whilst protein gains are particularly enhanced in skeletal muscle relative to other body tissues.
\end{abstract}

Some $\beta$-adrenergic agonists have the ability to increase lean gain at the expense of fat, which has led to the use of the term repartitioning agents (Asato et al. 1984). Clenbuterol (4-amino- $\alpha$-( $t$-butylamino-methyl)-3,5-dichlorobenzyl alcohol) and cimaterol (5-(1-hydroxy-2-(isopropylamino)-ethyl)anthranilonitrile) were identified by their ability to increase body-weight gain and decrease uterine fat pad weight in mice (Asato et al. 1984). Both compounds have been shown to increase carcass protein and decrease fat in sheep (Baker et al. 1984; Thornton et al. 1985; Wolff et al. 1987), cattle (Ricks et al. 1984), poultry (Asato et al. 1984; Dalrymple et al. 1984) and pigs (Jones et al. 1985). These changes are desirable in view of consumer demand for leaner meat. In addition, $\beta$-agonists provide a powerful tool for understanding the factors determining body composition in general and muscle growth in particular. Accordingly, several studies have been aimed at elucidating the mechanism of action of these compounds (Emery et al. 1984; Thornton et al. 1985; Reeds et al. 1986; Bohorov et al. 1987). However, none of the studies to date have included detailed information on initial and final weights of body components, as well as feed intakes. Here we report on quantitative effects of cimaterol on changes in the weight and composition of various tissues in growing rats and on feed intake and energetic efficiency.

\section{MATERIALS AND METHODS}

Male Sprague-Dawley rats, 6-7 weeks of age and mean body-weight 146.5 (SE 4.3) g, were housed in individual stainless-steel cages and fed on a semi-synthetic diet (obtained from Applied Biochemistry Division, New Zealand Department of Scientific and Industrial Research, Palmerston North). Diet composition (g/kg) was: lactalbumin 120, starch 690, maize oil 80, cellulose 100, mineral mix 50, vitamin mix 50 (James \& Treloar, 1981). Metabolizable energy (ME; $17.75 \mathrm{~kJ} / \mathrm{g}$ dry matter) content of the diet was determined using a separate group of similar rats. Following a $7 \mathrm{~d}$ period of adaptation to the diet, a 
Table 1. Initial tissue and component weights $(g)$ of rats, with regression coefficients used for prediction

(Model fitted was $y=b_{0}+b_{1} \times$ body-weight)

\begin{tabular}{|c|c|c|c|c|c|c|}
\hline Tissue & Component & Mean & SEM & $b_{0}$ & $b_{1}$ & $R$ \\
\hline Body & $\begin{array}{l}\text { Wt } \\
\text { Protein } \\
\text { Fat }\end{array}$ & $\begin{array}{l}146.5 \\
25.16 \\
15.44\end{array}$ & $\begin{array}{l}4 \cdot 3 \\
0 \cdot 80 \\
0 \cdot 57\end{array}$ & $\begin{array}{r}-1.94 \\
-3.90\end{array}$ & $\begin{array}{l}-\overline{0} \\
0 \cdot 185 \\
0 \cdot 132\end{array}$ & $\begin{array}{l}- \\
0.98 \\
0.88\end{array}$ \\
\hline Carcass & $\begin{array}{l}\text { Wt } \\
\text { Protein } \\
\text { Fat }\end{array}$ & $\begin{array}{r}63.69 \\
11.47 \\
5.66\end{array}$ & $\begin{array}{l}2 \cdot 17 \\
0 \cdot 38 \\
0 \cdot 25\end{array}$ & $\begin{array}{l}-9.56 \\
-1.35 \\
-2.82\end{array}$ & $\begin{array}{l}0.500 \\
0.0875 \\
0.0579\end{array}$ & $\begin{array}{l}0.99 \\
0.98 \\
0.80\end{array}$ \\
\hline Liver & $\begin{array}{l}\text { Wt } \\
\text { Protein } \\
\text { Fat }\end{array}$ & $\begin{array}{l}6.98 \\
1 \cdot 18 \\
0.24\end{array}$ & $\begin{array}{l}0.23 \\
0.04 \\
0.009\end{array}$ & $\begin{array}{l}-0.68 \\
-0.200 \\
-0.061\end{array}$ & $\begin{array}{l}0.0523 \\
0-00942 \\
0 \cdot 00205\end{array}$ & $\begin{array}{l}0.80 \\
0.85 \\
0.68\end{array}$ \\
\hline GI tract & $\begin{array}{l}\text { Wt } \\
\text { Protein } \\
\text { Fat }\end{array}$ & $\begin{array}{l}9.04 \\
1.08 \\
0.50\end{array}$ & $\begin{array}{l}0.12 \\
0 \cdot 02 \\
0 \cdot 01\end{array}$ & $\begin{array}{l}4.95 \\
0.459 \\
0.149\end{array}$ & $\begin{array}{l}0.0279 \\
0 \cdot 00424 \\
0 \cdot 00239\end{array}$ & $\begin{array}{l}0.57 \\
0-82 \\
0.45\end{array}$ \\
\hline Heart & $\begin{array}{l}\text { Wt } \\
\text { Protein }\end{array}$ & $\begin{array}{l}0.70 \\
0.13\end{array}$ & $\begin{array}{l}0.017 \\
0.003\end{array}$ & $\begin{array}{l}0 \cdot 111 \\
0.0243\end{array}$ & $\begin{array}{l}0.00400 \\
0.000718\end{array}$ & $\begin{array}{l}0.74 \\
0.67\end{array}$ \\
\hline Muscle & $\begin{array}{l}\text { Wt } \\
\text { Protein }\end{array}$ & $\begin{array}{l}0.80 \\
0.17\end{array}$ & $\begin{array}{l}0.02 \\
0.004\end{array}$ & $\begin{array}{l}0.124 \\
0.0197\end{array}$ & $\begin{array}{l}0 \cdot 00460 \\
0 \cdot 00101\end{array}$ & $\begin{array}{l}0.87 \\
0.83\end{array}$ \\
\hline Skin & $\begin{array}{l}\text { Wt } \\
\text { Protein } \\
\text { Fat }\end{array}$ & $\begin{array}{r}22 \cdot 45 \\
5 \cdot 07 \\
5 \cdot 42\end{array}$ & $\begin{array}{l}0.68 \\
0.20 \\
0.16\end{array}$ & $\begin{array}{r}-0.55 \\
-1.83 \\
0.17\end{array}$ & $\begin{array}{l}0.157 \\
0 \cdot 0471 \\
0.0358\end{array}$ & $\begin{array}{l}0 \cdot 95 \\
0 \cdot 94 \\
0 \cdot 74\end{array}$ \\
\hline Remainder & $\begin{array}{l}\text { Wt } \\
\text { Protein } \\
\text { Fat }\end{array}$ & $\begin{array}{r}34.01 \\
5.89 \\
3.56\end{array}$ & $\begin{array}{l}0.82 \\
0.15 \\
0.15\end{array}$ & $\begin{array}{l}6.18 \\
0.913 \\
-1.35\end{array}$ & $\begin{array}{l}0 \cdot 190 \\
0.0340 \\
0.0335\end{array}$ & $\begin{array}{l}0.97 \\
0.89 \\
0.91\end{array}$ \\
\hline
\end{tabular}

GI, Gastrointestinal; muscle, gastrocnemius plus plantaris (average of both sides).

representative group of twelve rats was killed to provide estimates of initial body composition, and six rats were assigned to each treatment group. Treatments consisted of the basal diet with cimaterol (American Cyanamid Co., Princeton, New Jersey) added at 0,25 or $150 \mathrm{mg} / \mathrm{kg}$. All animals were fed ad lib.

After $12 \mathrm{~d}$ of treatment, experimental rats were bled, killed and dissected; liver, empty gastrointestinal (GI) tract, heart, gastrocnemius plus plantaris muscles, skin (with hair), carcass and remainder (head, feet and tail plus remaining organs) were weighed and frozen pending analysis. Water and fat contents were determined as the weight losses following freeze-drying and Soxhlet extraction with light petroleum (b. p. $40-60^{\circ}$ ) respectively. Crude protein was calculated as Kjeldahl nitrogen $\times 6 \cdot 25$. Due to insufficient tissue mass, fat contents of gastrocnemius plus plantaris muscles and heart were not measured.

Initial tissue weights and compositions were estimated from body-weight, using regression equations derived from the initial slaughter group (Table 1). Net tissue weight, protein and fat gains were calculated from the final composition of each animal and its estimated initial composition. Results were analysed by analysis of covariance (Steel \& Torrie, 1981). We originally intended to adjust data for initial body-weight, however, it was not a significant covariate. Adjustment of tissue and component gain data for differences in weight gain during the week before treatment produced significant reductions in residual error. In addition, all slopes were positive, indicating that the effect of covariance adjustment was to correct for true differences in growth rate. Significant differences $(P<0.05)$ were examined further using Duncan's new multiple-range test (Steel \& Torrie, $1981)$. 
Table 2. Effects of cimaterol on rat body and tissue gains, adjusted for differences in initial weight gain during the week before treatment

\begin{tabular}{|c|c|c|c|c|c|c|c|c|}
\hline $\begin{array}{l}\text { Cimaterol } \\
(\mathrm{mg} / \mathrm{kg} \text { diet })\end{array}$ & Body & Carcass & Liver & GI tract & Heart & Muscle & Skin & Remainder \\
\hline \multicolumn{9}{|c|}{ Wt gains $(\mathrm{g} / 12 \mathrm{~d})$} \\
\hline 0 & $62 \cdot 9^{\mathrm{a}}$ & 30.9 & $2 \cdot 55$ & $0 \cdot 17$ & $0 \cdot 18$ & $0 \cdot 37^{\mathrm{b}}$ & $9 \cdot 79^{\mathrm{a}}$ & $12 \cdot 53^{\mathrm{a}}$ \\
\hline 25 & $57 \cdot 5^{\mathrm{ab}}$ & $32 \cdot 7$ & 1.31 & $0 \cdot 14$ & 0.21 & $0.55^{\mathrm{a}}$ & $4 \cdot 12^{n}$ & $9.91^{\mathrm{b}}$ \\
\hline 150 & $49 \cdot 4^{b}$ & $28 \cdot 7$ & 1.43 & $-0 \cdot 45$ & 0.26 & $0.49^{a}$ & $2 \cdot 10^{\mathrm{b}}$ & $8.57^{\mathrm{h}}$ \\
\hline SEM & $3 \cdot 1$ & $1 \cdot 6$ & $0 \cdot 37$ & $0 \cdot 36$ & 0.03 & 0.03 & 0.87 & 0.72 \\
\hline Statistical significance & $*$ & NS & $\dagger$ & NS & NS & $* *$ & $* * *$ & $* *$ \\
\hline \multicolumn{9}{|c|}{ Protein gains $(\mathrm{g} / 12 \mathrm{~d})$} \\
\hline 0 & 11.81 & $6 \cdot 27^{b}$ & 0.37 & 0.07 & 0.03 & $0 \cdot 09^{\mathrm{h}}$ & $2 \cdot 60$ & $2 \cdot 29$ \\
\hline 25 & $13 \cdot 32$ & $8 \cdot 00^{a}$ & $0 \cdot 30$ & 0.03 & 0.04 & $0 \cdot 14^{\mathrm{a}}$ & $2 \cdot 41$ & $2 \cdot 27$ \\
\hline 150 & $11 \cdot 17$ & $7.05^{\mathrm{ab}}$ & $0 \cdot 27$ & -0.02 & 0.05 & $0.12^{\mathrm{a}}$ & 1.47 & $2 \cdot 13$ \\
\hline SEM & $0 \cdot 70$ & $0 \cdot 33$ & $0 \cdot 05$ & 0.04 & 0.005 & 0.006 & $0 \cdot 35$ & $0 \cdot 13$ \\
\hline Statistical significance & NS & $*$ & NS & NS & NS & $* * *$ & $\dagger$ & NS \\
\hline \multicolumn{9}{|c|}{ Fat gains $(g / 12 d)$} \\
\hline 0 & $6.03^{a}$ & $2 \cdot 41^{\mathrm{a}}$ & $0.09^{a}$ & $0.07^{\mathrm{a}}$ & ND & ND & $1 \cdot 60^{\mathrm{a}}$ & $1.91^{\mathrm{a}}$ \\
\hline 25 & $-0.14^{b}$ & $0 \cdot 34^{b}$ & $-0.01^{b}$ & $-0.09^{b}$ & ND & ND & $-0.66^{h}$ & $0 \cdot 34^{\mathrm{b}}$ \\
\hline 150 & $-1.92^{b}$ & $-0.59^{b}$ & $0.02^{b}$ & $-0 \cdot 14^{b}$ & ND & ND & $-1 \cdot 29^{\mathrm{b}}$ & $0 \cdot 15^{\mathrm{b}}$ \\
\hline SEM & 0.93 & $0 \cdot 38$ & 0.04 & 0.04 & ND & ND & $0 \cdot 36$ & $0 \cdot 28$ \\
\hline Statistical significance & $* * *$ & $* * *$ & $* * *$ & $* *$ & - & - & $* * *$ & $* *$ \\
\hline
\end{tabular}

GI, Gastrointestinal ; muscle, combined gastrocnemius plus plantaris muscles (average of both sides) : ND, not determined; NS, not significant.

a, b Means in the same column with different superscript letters were significantly different $(P<0 \cdot 05)$.

Statistical significance : $+P<0 \cdot 10 ; * P<0.05 ; * * P<0 \cdot 01 ; * * * P<0.001$.

Body-weight gains included blood and GI-tract contents, therefore were greater than the sum of tissue gains.

Table 3. Effects of cimaterol on daily metabolizable energy intake, energy retention and heat production $\left(\mathrm{kJ} / \mathrm{kg}\right.$ body-weight $\left.{ }^{0.75}\right)$ in growing rats

\begin{tabular}{lccc}
\hline $\begin{array}{l}\text { Cimaterol } \\
(\mathrm{mg} / \mathrm{kg} \text { diet })\end{array}$ & Metabolizable energy intake & Retained energy & Heat production \\
\hline 0 & 939 & $163^{\mathrm{a}}$ & $776^{\mathrm{b}}$ \\
25 & 938 & $75^{\mathrm{b}}$ & $863^{\mathrm{a}}$ \\
150 & 934 & $72^{\mathrm{b}}$ & $863^{\mathrm{a}}$ \\
SEM & 11 & 13 & 13 \\
Statistical significance & NS & $* * *$ & $* *$ \\
\hline
\end{tabular}

NS, Not significant.

a,b Means in the same column with different superscript letters were significantly different $(P<0-05)$.

Statistical significance: ${ }^{* *} P<0.01 ;{ }^{* *} P<0.001$.

In order to evaluate changes in energy utilization accompanying the altered growth pattern in cimaterol-fed rats, the amounts of energy ingested, retained in body tissues and released as heat by each animal were calculated. ME intake was estimated from individual feed intake and the ME content of the diet. Retained energy (RE) was calculated assuming that body protein contains $23.85 \mathrm{~kJ} / \mathrm{g}$ (Kleiber, 1961) and using a measured value of $39 \cdot 15 \mathrm{~kJ} / \mathrm{g}$ for fat. Heat production (HE) was estimated as the difference between $\mathrm{ME}$ intake and RE. 


\section{RESULTS}

Initial tissue and component weights, along with the appropriate regression coefficients, are given in Table 1. Body-weight gains decreased with cimaterol treatment in a dosedependent fashion, largely due to lower gains in skin and remainder (Table 2). On the other hand, muscle weight gain was increased by cimaterol from $0.37 \mathrm{~g}$ in controls to 0.55 and $0.49 \mathrm{~g}$ (i.e. 49 and $32 \%$ higher) in 25 and $150 \mathrm{mg}$ cimaterol $/ \mathrm{kg}$ groups respectively. Protein gain was increased in muscle at both dosages and in carcass $(25 \mathrm{mg}$ cimaterol $/ \mathrm{kg}$ group only). Other tissues, notably skin, liver and GI tract tended to gain less protein in treated groups $(P>0.05)$, resulting in non-significant changes in whole-body protein gain. Fat gains were significantly affected in all tissues (Table 2); whole-body fat gain was $6.03 \mathrm{~g}$ in controls, whilst cimaterol-fed rats lost 0.14 and $1.92 \mathrm{~g} \mathrm{(25} \mathrm{and} 150 \mathrm{mg}$ cimaterol $/ \mathrm{kg}$ groups respectively).

Actual empty body compositions for the 0,25 and $150 \mathrm{mg}$ cimaterol $/ \mathrm{kg}$ groups respectively were $(\mathrm{g} / \mathrm{kg}$ ): water, 660,680 and 686 (SEM 5, $P<0.05$ ); protein, 189, 206 and 201 (SEM 2, $P<0.001$ ); fat, 110, 79 and 74 (SEM 6, $P<0.01$ ). Ratios of body water :protein were $3.49,3.31$ and 3.41 for the 0,25 and $150 \mathrm{mg}$ cimaterol/ $\mathrm{kg}$ groups respectively (SEM $0.04, P<0.05)$.

ME intake was not affected by cimaterol (Table 3). However, RE was sharply reduced $(P<0.001)$ in cimaterol-fed rats, and calculated $\mathrm{HE}$ was about $863 \mathrm{~kJ} / \mathrm{kg}$ body-weight ${ }^{0.75}$, i.e. $11 \%$ higher in both treated groups (Table 3). As a result, gross efficiency was reduced from $17.4 \%$ in controls to $8.0 \%$ and $7.7 \%$ in the 25 and $150 \mathrm{mg}$ cimaterol $/ \mathrm{kg}$ groups respectively.

\section{DISCUSSION}

The aim of the present study was to determine quantitatively the effects of cimaterol on rat growth, body composition and efficiency of energy utilization. Responses observed in the present study were generally in agreement with those reported previously. Cimaterol demonstrated clear repartitioning effects in growing rats, increasing protein gain at the expense of fat. Previous reports of the repartitioning effects of $\beta$-agonists have concentrated on changes in whole-body protein and fat. Our results define more precisely the tissues affected by cimaterol.

Cimaterol treatment resulted in a loss of whole-body fat (Table 2). At the tissue level, this was due to either decreased gain or actual loss of fat; these effects were highly significantly in all tissues. Fat in skin, reflecting mainly subcutaneous adipose depots, was most sensitive to the drug, whereas fat in remainder, largely comprising internal adipose depots, was least sensitive. This selectivity may have practical importance, since subcutaneous fat is more likely to accompany the carcass of meat animals than abdominal fat.

The effects of cimaterol on protein gains were also not uniform among tissues. Treated animals gained significantly more protein in carcass and gastrocnemius plus plantaris muscles, and tended to gain more protein in heart $(P>0.05)$. Protein gains in other tissues were lower in treated rats, although these differences were not significant. Carcass protein gain was not significantly increased in the $150 \mathrm{mg}$ cimaterol $/ \mathrm{kg}$ group relative to controls. Coupled with decreased gains in other non-muscle tissues, this resulted in a slight (non-significant) decrease in whole-body protein gain at the highest dose of cimaterol. The reason for this loss of activity is not clear. Possibly, there is some down-regulation of receptors in muscle at very high dosages. On the other hand, the effects of cimaterol on fat tended to be greater at $150 \mathrm{mg} / \mathrm{kg}$ than at $25 \mathrm{mg} / \mathrm{kg}$. This supports the conclusion of Sainz \& Wolff (1987) that cimaterol must have specific effects in both muscle and adipose tissue to produce the observed changes in body composition. 
Body water increased from $660 \mathrm{~g} / \mathrm{kg}$ in controls to $680 \mathrm{~g} / \mathrm{kg}$ in cimaterol-treated rats, in parallel with the increase in body protein from 190 to $200 \mathrm{~g} / \mathrm{kg}$. However, body protein content increased proportionately more than water content, resulting in a lower water: protein ratio (WPR) in the $25 \mathrm{mg}$ cimaterol $/ \mathrm{kg}$ group (3.31 compared with 3.49 in controls, a $5 \%$ reduction). The ratio of body water:protein is not constant, and indeed has been proposed as an index of physiological maturity (Bailey et al. 1960). In addition, WPR can be altered by nutritional state (Mendez, 1966; Suzuki et al. 1975). However, $\beta$-agonists do not appear to alter WPR in lambs (Baker et al. 1984), calves (Williams et al. 1986) or steers (Ricks et al. 1984). In contrast, WPR decreased 3.1\% from 3.81 in controls to 3.69 in clenbuterol-treated rats (Rothwell et al. 1984). Emery et al. (1984) reported a 9.3\% reduction of WPR, from 3.45 in controls to 3.13 in rats treated with clenbuterol, whilst fenoterol had no effect on WPR. Similarly, clenbuterol produced 5.5 and $11.3 \%$ reductions in WPR in normal and dystrophic mice respectively (Rothwell \& Stock, 1985). Possibly, differences in tissue components other than protein which bind water (e.g. glycogen) may contribute to observed changes in WPR. The present study is in agreement with demonstrated reductions of WPR in rodents treated with clenbuterol. The reason for the different response of WPR to $\beta$-agonists observed in ruminant livestock species and laboratory rodents is not clear.

In the present study, cimaterol did not affect energy intake, while decreasing energy retention and increasing heat production (Table 3 ). These results contrast with those of Emery et al. (1984), who reported that clenbuterol increased ME intake and energy expenditure, without affecting energy gain in rats. The major difference appears to be that in the present study, rats did not increase food intake to compensate for increased energy expenditures, resulting in mobilization of fat reserves to provide substrates for oxidation. Differences in dosage are probably not responsible for these discrepancies. Emery et al. (1984) used a daily dose of $2 \mathrm{mg}$ clenbuterol $/ \mathrm{kg}$ body-weight; in the present study, rats consumed about 2.3 and $13.8 \mathrm{mg}$ cimaterol $/ \mathrm{kg}$ body-weight in the 25 and $150 \mathrm{mg} / \mathrm{kg}$ diets respectively. Possibly, these differences are due to the method of delivery, since in the Emery et al. (1984) study clenbuterol was injected twice daily, whereas we incorporated cimaterol in the diet. Also, these drugs may differ in their metabolic effects in one or more tissues. Without information about receptor and tissue specificities, second messengers or changes in energy-utilizing processes due to cimaterol and clenbuterol, these differences must remain unresolved.

In conclusion, the present study has demonstrated that cimaterol produces similar effects in rats as in sheep, i.e. protein gain is increased at the expense of fat. In addition, muscle growth was particularly enhanced by this $\beta$-adrenergic agonist, in agreement with reports of increased yields of saleable meat in livestock. As was pointed out by Reeds et al. (1986), $\beta$-agonists may provide an important tool in the elucidation of factors limiting muscle growth and therefore controlling meat production. Identification of the mechanism(s) of action of $\beta$-agonists will undoubtedly improve our understanding of the factors controlling growth and body composition.

A fellowship from the New Zealand National Research Advisory Council for R.D.S. is gratefully acknowledged. The authors thank Mr B. Coe, Mr P. Dobbie, Mr M. Familton and Ms D. Petrie for their assistance with animal care and dissection. Special thanks are due to American Cyanamid Co. for their donation of cimaterol and particularly Dr Roger DeLay for helpful comments during the preparation of the manuscript. 


\section{REFERENCES}

Asato, G., Baker, P. K., Bass, R. T., Bentley, T. J., Chari, S., Dalrymple, R. H., France, D. J., Gingher, P. E., Lences, B. L., Pascavage, J. J., Pensack, J. M. \& Ricks, C. A. (1984). Agricultural and Biological Chemistry 48, 2883-2888.

Bailey, C. B., Kitts, W. D. \& Wood, A. J. (1960). Canadian Journal of Animal Science 40, 143-155.

Baker, P. K., Dalrymple, R. H., Ingle, D. L. \& Ricks, C. A. (1984). Journal of Animal Science 59, $1256-1261$.

Bohorov, O., Buttery, P. J., Correia, J. H. R. D. \& Soar, J. B. (1987). British Journal of Nutrition 57, 99-107.

Dalrymple, R. H., Baker, P. K., Gingher, P. E., Ingle, D. L., Pensack, J. M. \& Ricks, C. A. (1984). Poultry Science 63, 2376-2383.

Emery, P. W., Rothwell, N. J., Stock, M. J. \& Winter, P. D. (1984). Bioscience Reports 4, 83-91.

James, K. A. C. \& Treloar, B. P. (1981). Journal of Nutrition 111, 1797-1804.

Jones, R. W., Easter, R. A., McKeith, F. K., Dalrymple, R. H., Maddock, H. M. \& Bechtel, P. J. (1985). Journal of Animal Science 61, 905-913.

Kleiber, M. (1961). The Fire of Life. New York: John Wiley.

Mendez, J. (1966). Journal of Nutrition 89, 513-519.

Reeds, P. J., Hay, S. M., Dorwood, P. M. \& Paimer, R. M. (1986). British Journal of Nutrition 56, $249-258$.

Ricks, C. A., Dalrymple, R. H., Baker, P. K. \& Ingle, D. L. (1984). Joumal of Animal Science 59, $1247-1255$.

Rothwell, N. J. \& Stock, M. J. (1985). Bioscience Reports 5, 755-760.

Rothwell, N. J., Stock, M. J. \& Winter, P. D. O'B. (1984). Proceedings of the Nutrition Society 43, 71A.

Sainz, R. D. \& Wolf, J. E. (1987). In Proceedings of the 2nd International Symposium on the Nutrition of Herbivores, pp. 153-154. Brisbane: Australian Society of Animal Production.

Steel, R. G. D. \& Torrie, J. H. (1981). Principles and Procedures of Statistics: A Biometrical Approach. New York: McGraw-Hill.

Suzuki, H., Goshi, H. \& Sugisawa, H. (1975). Journal of Nutrition 105, 90-95.

Thornton, R. F., Tume, R. K., Payne, G., Larsen, T. W., Johnson, G. W. \& Hohenhaus, M. A. (1985). Proceedings of the New Zealand Society of Animal Production 45, 97-101.

Williams, P. E. V., Pagliani, L. \& Innes, G. M. (1986). Livestock Production Science 15, 289-293.

Wolff, J. E., Dalrymple, R. H. \& Ingle, D. L. (1987). In Proceedings of the 4th Asian -Australasian Association of Animal Production Animal Science Congress, p. 490. Hamilton, New Zealand: AAAP Organising Committee. 